\title{
SISTEM INFORMASI MANAJEMEN \\ PADA PENJUALAN THRIFT TOKO YEGUMI BERBASIS WEB
}

Peneliti :

\author{
Novita Anjarsari(novitaanjarsari22@gmail.com) \\ Risky Nurfadila(kikyfadila1@gmail.com) \\ Iswatul Saldina(saldinaiswatul@gmail.com)
}

\begin{abstract}
:
This study is intended to determine how effective the use of a web-based Management Information System is for thrift sales at Yegumi Stores. In this study, the researcher provides an explanation of the web-based Yegumi store thrift sales management information system that is applied in the store which is associated with theoretical studies contained in previous studies.

The research method used is primary data with data analysis techniques through interviews with the owner of the Yegumi Shop. The results from our research show that Yegumi Store is very effective in using a web-based Management Information System, this is indicated by the increase in product sales, information about sales, stock availability, customer satisfaction, as well as financial reports that are easily obtained by internal parties.
\end{abstract}

Keywords: Management Information System (MIS), Sales, Thrift, Web-Based.

\begin{abstract}
Abstrak :
Penelitian ini dimaksudkan untuk mengetahui seberapa efektif penggunaan Sistem Informasi Manajemen berbasis web yang digunakan pada penjualan thrift Toko Yegumi. Pada penelitian ini, peneliti memberikan penjelasan mengenai system informasi manajemen penjualan thrift toko Yegumi berbasis web yang diterapkan di dalam toko tersebut yang dikaitkan dengan kajian teoritis yang terdapat pada kajian-kajian sebelumnya.

Metode penelitian yang digunakan merupakan data primer dengan teknik analisis data melalui interview pada owner Toko Yegumi. Hasil dari penelitian yang kami dapat bahwa Toko Yegumi sangat efektif menggunakan Sistem Informasi Manajemen berbasis web, ini ditandai dengan meningkatnya penjulan produk, Infromasi mengenai penjualan, ketersediaan stock, kepuasan pelanggan, dan juga laporan keuangan yang mudah di peroleh oleh pihak internal. .
\end{abstract}

Kata kunci: Sistem Informasi Manajemen (SIM), Penjualan, Thrift, Berbasis Web 


\section{PENDAHULUAN}

Kemajuan teknologi informasi yang pesat sesuai dengan kebutuhan hampir di setiap aspek sangat penting bagi kehidupan. Kemajuan teknologi informasi itu sendiri didukung oleh hadirnya internet yang dalam perkembangannya berkembang sangat pesat, karena hampir semua orang di seluruh dunia menggunakan internet. Saat ini model bisnis yang memiliki keunggulan kompetitif untuk bersaing yaitu dengan adanya jaringan internet. Internet dapat membantu meningkatkan penjualan suatu usaha karena mencangkup banyak kalangan dan banyak daerah. Salah satu komponen internet adalah aplikasi website yang mampu memecahkan masalah dalam melaksanakan segala aktifitas operasional.

Toko Thrift Yegumi merupakan suatu usaha yang bergerak di bidang penjualan baju bekas import maupun non-import dengan model korean style. Selama ini toko merasakan proses bisnis yang kurang memuaskan karena proses penjualan dan pemasaran tidak menggunkaan internet. Melihat kebutuhan ini maka perlu adanya sitem informasi secara online termasuk laporan yang berhubungan dengan informasi manajemen toko. Dalam hal ini akan sangat berguna bagi Toko Thrift Yegumi karena dengan internet dapat mencakup pasar yang luas guna memperkenalkan dan memasarkan produk yang tersedia pada Toko Thrift yegumi.

Berdasarkan hal tersebut maka peneliti akan mengaambil pembahsaan berupa, bagaimana prosedur sistem yang berjalan dalam penjualan Thrift Toko Yegumi, bagaimana cara menganalisis kendala pada system penjualan Thrift sebelum berbasis web dan bagaimana output sistem informasi manajemen pada Thrift Toko Yegumi akan diaplikasikan website. Sistem informasi penjualan produk baju yang dapat membantu konsumen dalam melakukan pemesanan produk yang lebih mudah dan cepat secara online, menyediakan informasi terbaru serta database yang dapat membantu dalam pengolahan data dan penyimpanan data saat dibutuhkan. Oleh karena itu, diperlukan suatu sistem yang bisa mengolah informasi penjualan sesuai kebutuhan pada Toko Thrift Yegumi. Berdasarkan hal diatas, maka penulis tertarik melakukan pengkajian dan pembahasan yang dituangkan dalam bentuk Tugas Akhir Semester dengan judul "Sistem Informasi Manajemen Pada Penjualan Thrift Toko Yegumi Berbasis Web 


\section{LANDASAN TEORI}

\section{Pengertian Sistem}

Sistem menurut McLeod yang dikutip dalam bukunya yang berjudul "Management Information System" adalah sekelompok elemen-elemen yang terintegrasi dengan maksud yang sama untuk mencapai tujuan (Laudon, 2010) .

Secara bebas dapat diartikan sistem adalah suatu entitas yang berusaha menjaga keberadaannya dengan melakukan hubungan yang menguntungkan dengan elemen-elemennya untuk mencapai tujuan. Bertalanfy mendefinisikan sistem dengan berfokus pada entitas, yaitu suatu obyek atau benda (hidup atau mati), eksistensi, dan tujuan (Heryana \& Unggul, 2018).

Menurut Satzinger, Jackson, dan Burd sistem merupakan sekumpulan komponen yang saling berhubungan dan bekerja bersama untuk mencapai suatu tujuan (Laudon, 2010). Bedasarkan kedua pengertian di atas, maka dapat disimpulkan bahwa pengertian sebuah sistem adalah sekumpulan elemen yang terintegasi dan bekerja bersama guna mencapai suatu tujuan tertentu.

\section{Arti Penting Pengembangan Sistem}

Pengembangan sistem (systems development) merupakan menyusun suatu sistem yang baru untuk menggantikan sistem yang lama secara keseluruhan atau memperbaiki sistem yang telah ada (Prabowo, 2015). Sistem yang lama perlu diperbaiki atau diganti disebabkan karena beberapa hal, yaitu sebagai berikut ini:

1. Adanya permasalahan-permasalahan (problems) yang timbul di sistem yang lama.

2. Ketidakberesan dalam sistem yang lama menyebabkan sistem yang lama tidak dapat beroperasi sesuai dengan yang diharapkan.

3. Kecurangan-kecurangan disengaja yang menyebabkan tidak amannya harta kekayaan perusahaan dan kebenaran dari data menjadi kurang terjamin.

4. Kesalahan-kesalahan yang tidak disengaja yang juga dapat menyebabkan kebenaran dari data kurang terjamin.

5. Tidak efisiennya operasi.

6. Tidak ditaatinya kebijaksanaan manajemen yang telah ditetapkan. 


\section{Siklus Hidup Pengembangan Sistem}

Siklus hidup pengembangan sistem menggambarkan periode pengembangan dan periode setelah pengembangan dari satu siklus hidup sistem informasi. Siklus hidup ini terdiri dari tahap proses perencanaan, anlisis, desain, implementasi,dan operasi meliputi beberapa aktivitas dan berakhir dengan output yang tampak yang disebut deliverable. Pengembangan sistem merupakan proses berkelanjutan yang tidak berakhir setelah sistem beroperasi (Prabowo, 2015). Ada tiga alasan perlunya pengembangan yang berkelanjutan:

1. Adanya perubahan yang tidak dapat dihindari baik dalam perusahaan maupun lingkungan perusahaan.

2. Munculnya kelemahan. Manajer baru dapat diangkat untuk memberikan informasi yang lebih baik untuk pengambilan keputusan. Kelemahan ini dapat diatasi melalui perbaikan sistem informasi.

3. Perbaikan dalam teknologi informasi dapat mengubah dengan hardware dan software komputer.

\section{Tujuam Pengembangan Sistem}

1. Sistem yang dihasilkan harus dapat menghasilkan informasi yang cermat dan tepat waktu (informasi yang diterima penggunanya tepat pada saat diperlukan untuk mengambil keputusan)

2. Pengembangan sistem harus dapat diselesaikan dalam jangka waktu yang layak

3. Sistem harus dapat memberikan kepuasan kepada penggunanya

\section{Daur Pengembangan Sistem}

Tahapan daur pengembangan sistem terdiri dari beberapa tahap, yaitu:

1. Perencanaan sistem

2. Analisis sitem

3. Desain sistem

4. Implementasi sistem

5. Operasionalisasi system

\section{Pengertian Informasi}

Informasi menurut McLeod merupakan data yang telah diproses atau memiliki arti (Laudon, 2010). Adapun karakteristik penting yang harus dimiliki oleh informasi, seperti: relevansi, akurat, ketepatan waktu, dan kelengkapan. Informasi adalah kenyataan yang tampak 
maupun yang tidak tampak yang tersedia untuk mengurangi ketidakpastian tentang beberapa keadaan atau kejadian.

Menurut Gordon B. Davis: "Informasi adalah data yang telah diolah ke dalam suatu bentuk yang berguna bagi penerimanya dan nyata atau berupa nilai yang dapat dipahami di dalam keputusan sekarang maupun masa depan.” (Laudon, 2010) .

Dari beberapa definisi informasi yang diberikan oleh beberapa pengarang, dapat diambil kesimpulan bahwa informasi adalah:
a. data yang diolah
b. menjadi bentuk yang lebih berguna dan lebih berarti bagi yang menerimanya
c. menggambarkan suatu kejadian - kejadian (event) dan kesatuan nyata (fact dan entity)
d. digunakan untuk pengambilan keputusan

\section{Sistem Informasi Manajemen}

Sistem informasi akan membantu perusahaan untuk menyajikan laporan keuangan ke dalam bentuk informasi yang akurat dan terpercaya, sehingga banyak pihak yang memanfaatkan sistem informasi akuntansi untuk mencapai keunggulan bagi perusahaan (Purnama, 2016)

Menurut Whitten, Bentley, dan Ditman sistem informasi adalah pengaturan orang, data, proses, dan informasi (TI) atau teknologi informasi yang berinteraksi untuk mengumpulkan, memproses, menyimpan, dan menyediakan sebagai output informasi yang diperlukan untuk mendukung sebuah intansi atau organisasi (Laudon, 2010) .

Menurut O'Brien mengatakan bahwa komponen Sistem Informasi terbagi atas beberapa hal (Laudon, 2010), yaitu:

a) Sumber daya data (sebagai data dan pengetahuan).

b) Sumber daya Manusia (sebagai pemakai akhir dan ahli SI).

c) Sumber daya software (sebagai program dan prosedur).

d) Sumber daya hardware (mesin dan media).

e) Sumber daya jaringan (sebagai media komunikasi dan dukungan jaringan).

Bedasarkan dari pernyataan di atas, maka dapat disimpulkan bahwa Sistem informasi merupakan suatu sistem yang mempunyai kemampuan untuk mengumpulkan informasi dari semua sumber dan menggunakan berbagai media untuk menampilkan informasi. 
Sistem Informasi Manajemen atau SIM menurut McLeod dan Schell dalam Zakiyudin adalah suatu sistem berbasis komputer yang membuat informasi tersedia bagi para pengguuna yang memiliki kebutuhan serupa (Murdick dan Ross, 2005).

Adapun menurut Murdick dan Ross Sistem Infromasi Manajemen merupakan proses komunikasi di mana informasi masukan (input) direkam, disimpan, dan diproses untuk menghasilkan output yang berupa keputusan tentang perencanaan, pengoperasian dan pengawasan (Murdick dan Ross, 2005).

Berdasarkan berbagai pernyataan tersebut, dapat ditarik kesimpulan bahwa SIM merupakan pengelolaan sumber daya informasi secara efektif dan efisien untuk meningkatkan kinerja organisasi.

\section{Tugas Sistem Informasi Manajemen menurut (Murdick dan Ross, 2005) terdiri atas:}

1. Pengumpulan Data Bagian pengumpul data bertugas untuk mengumpulkan data baik dari dalam organisasi maupun dari luar organisasi. Pihak dalam perusahaan yang menjalankan tugas ini diambil dari seluruh unit kerja yang ada dalam organisasi, sehingga setiap unit kerja terwakili dalam SIM.

2. Penyimpanan Data Data yang telah terkumpul selanjutnya disimpan untuk segera diproses atau ditunda pemrosesannya, tergantung kebutuhan para manajer.

3. Pemrosesan Data Pemrosesan data dapat dilakukan oleh satu atau beberapa ahl. Bila datanya terlalu banyak, jasa dari tenaga-tenaga pengumpul dan insidential dapat dimanfaatkan. Bagian inilah yang membuat data itu berubah bentuk menjadi informasi yang disesuaikan dengan permintaan manajer.

4. Pemprogram Data Setiap komputer memiliki bahasanya sendiri-sendiri. Agar komputer dapat melaksanakan tugasnya, maka perintah-perintah terhadap data yang terkumpul harus diubah terlebih dahulu sesuai dengan bahasa yang digunakan. Pekerjaan inilah yang disebut memprogram, yang biasa dilakukan oleh orang-orang yang ahli di bidang komputer.

\section{Fungsi Sistem Informasi Manajemen pada Bisnis}

1. Membantu dalam proses pengambilan keputusan

2. Membantu dalam menemukan suatu masalah

3. Membantu dalam hal membandingkan kinerja bisnis

4. Membantu dalam hal koordinasi antar departemen 


\section{Tahapan Proses Manajemen}

Proses manajemen memiliki beberapa tahapan yang dapat didefinisikan sebagai berikut:

1. Perencanaan

2. Pengendalian

3. Pengambilan Keputusan

\section{Komponen Sistem Informasi Manajemen}

1. Manusia

Di dalam sebuah SIM, manusia merupakan peranan yang sangat penting. Peran dari manusia sendiri adalah merancang, mengolah, mengoperasikan, membangun, dan menggunakan sistem tersebut.

2. Informasi

Sistem informasi manajemen dibuat oleh manusia untuk menghasilkan informasi dari data yang bersifat mentah sehingga menjadi data yang dapat diolah dan dapat berguna bagi bisnis. Informasi yang berguna disini adalah informasi yang relevan, dapat dibandingkan, memiliki akurasi tinggi, tepat waktu, dan dapat dipertanggungjawabkan.

\section{Sistem}

Sistem informasi manajemen adalah sebuah sistem besar dimana terbentuk dari beberapa subsistem yang berbeda tugasnya, tetapi saling terhubung dan terintegrasi. Subsistem dalam sistem informasi manajemen bertugas untuk mengumpulkan, mengolah, dan menyempurnakan data sehingga menghasilkan sebuah informasi.

4. Organisasi manajemen

Setiap usaha dan bisnis membentuk organisasi manajemen untuk mencapai tujuan dari usaha dan bisnisnya. Fungsi dari organisasi manajemen sendiri adalah untuk mengorganisir, melaksanakan, merencanakan, dan mengontrol operasional perusahaan atau organisasi.

5. Pengambilan keputusan

Pengambilan keputusan dapat diambil apabila bisnis tersebut memiliki informasi yang relevan dan dapat dipertanggungjawabkan. Seorang pebisnis maupun pengusaha tidak dapat mengambil keputusan dengan baik apabila tidak adanya SIM sebagai wadah untuk mengelola informasi. 


\section{Penjualan}

Pengertian penjualan menurut Henry Simamora menyatakan bahwa penjualan adalah lazim dalam perusahaan dan merupakan jumlah kotor yang dibebankan kepada pelanggan atas barang dan jasa.

Penjualan menurut Chairul Marom penjualan artinya Penjualan barang dengan sebagai usaha pokok perusahaan yang biasa dilakukan secara teratur. Penjualan Menurut Winardi mengatakan bahwa Penjualan merupakan sebuah proses dimana kebutuhan pembeli dan kebutuhan penjual dipenuhi, melalui antar pertukaran dan kepentingan.

Berdasarkan pengertian diatas, maka dapat disimpulkan bahwa Penjualan adalah persetujuan kedua belah pihak antara penjual dan pembeli, dimana penjual menawarkan suatu produk dengan harapan pembeli dapat menyerahkan sejumlah uang sebagai alat ukur produk tersebut sebesar harga jual yang telah disepakati. Kegiatan penjualan dapat tercipta suatu proses penukaran barang atau jasa antara penjual dan pembeli. Dalam perekonomian, seorang yang menjual sesuatu akan mendapatkan imbalan beberapa uang. Dengan alat penukaran berupa uang, orang akan lebih mudah memenuhi segala keinginannya dan penjualan akan lebih mudah dilakukan. b) Faktor-faktor yang mempengaruhi Penjualan Aktifitas penjualan banyak dipengaruhi oleh faktor tertentu yang dapat meningkatkan aktifitas perusahaan, oleh karena itu manager penjualan perlu memperhatikan faktor-faktor yang mempengaruhi penjualan. Menurut Basu Swastha , Faktor - faktor yang mempengaruhi penjualan antara lain sebagai berikut :

1. Kondisi dan Kemampuan Penjual (sales skill) Sales Skill (keahlian menjual) adalah suatu keahlian yang harus dikuasai oleh salesman untuk menciptakan proses penjualan yang berhasil. Ada yang berpendapat keahlian ini merupakan bakat yang dibawa sejak lahir

2. Kondisi pasar. Pasar adalah suatu tempat fisik di mana pembeli dan penjual berkumpul untuk mempertukarkan barang dan jasa, Sedangkan pendapat lain mengatakan bahwa pasar adalah orang-orang yang mempunyai keinginan untuk puas, uang untuk berbelanja, dan kemauan untuk membelanjakannya

3. Modal Menurut Bambang Riyanto14 pengertian modal usaha sebagai ikhtisar neraca suatu perusahaan yang menggunakan modal konkrit dan modal abstrak. Modal konkrit dimaksudkan sebagai modal aktif sedangkan modal abstrak dimaksudkan sebagai modal pasif.

4. Promosi Faktor - faktor ini, seperti: periklanan, peragaan, kampanye, pemberian hadiah, sering mempengaruhi penjualan. Namun untuk melaksanakannya, diperlukan sejumlah 
dana yang tidak sedikit. Bagi perusahaan yang bermodal kuat, kegiatan ini secara rutin dapat dilakukan.

\section{Toko Thirft}

Sesuai dengan namanya, arti thrift adalah penghematan atau cara dalam penggunaan uang dengan menghindari pemborosan dan store berarti toko. Arti Thrift shop adalah toko atau usaha yang menjual barang-barang bekas dari luar maupun dalam negeri. Disebut juga sebagai toko penghematan. Sejak tahun 2013, perdagangan barang bekas mulai masuk ke Indonesia, dimulai dari barang langka hingga barang dengan brand yang terkenal. Akan tetapi, dalam bisnis thrift shop, apapun barang serta nama brand nya, selama barang bekas tersebut berkondisi baik dan layak untuk dipakai memiliki arti dapat diperjualbelikan.

\section{Berbasis Web}

Website adalah suatu kumpulan-kumpulan halaman yang menampilkan berbagai macam informasi teks, data, gambar, video maupun gabungan dari semuanya bersifat statis dan dinamis. Sebelum dibahas lebih lanjut, tentunya terlebih dahulu mengetahui pengertian web.

World Wide Web atau WWW atau juga dikenal dengan WEB adalah salah satu layanan yang didapat oleh pemakai computer yang terhubung ke internet (Rahmat, 2010). Web ini menyediakan informasi bagi pemakai computer yang terhubung ke internet dari sekedar informasi "sampah" atau informasi yang tidak berguna sama sekali sampai informasi yang serius; dari informasi yang gratisan sampai informasi yang komersial.

Berdasarkan teori diatas dapat disimpulkan bahwa pengertian web adalah suatu sistem yang menudahkan pencarian informasi untuk menampilkan teks, gambar, multimedia dan lain sebagainya pada jaringan internet. Internet adalah seluruh jaringan komputer yang saling terhubung menggunakan standar sistem global Transmission Control Protocol/Internet Protocol Suite (TCP/IP) sebagai protokol pertukaran paket (packet switching communication protocol) untuk melayani milayaran pengguna di seluruh dunia. Menurut Sibero (2014:10), Internet merupakan kependekan dari kata "Interconnected Network" yang berarti jaringan komputer yang menghubungkan antar jaringan secara global, internet dapat juga disebut jaringan dalam suatu jaringan yang luas. Seperti halnya jaringan komputer lokal maupun jaringan komputer area, internet juga menggunakan protokol komunikasi yang sama yaitu TCP/IP (Transmission Control Protokol / Internet Protocol). 


\section{METODE PENELITIAN}

\section{Gambar 1. Kerangka Konseptual}

Menjelaskan mengenai system informasi manajemen penjualan thrift toko Yegumi berbasis web

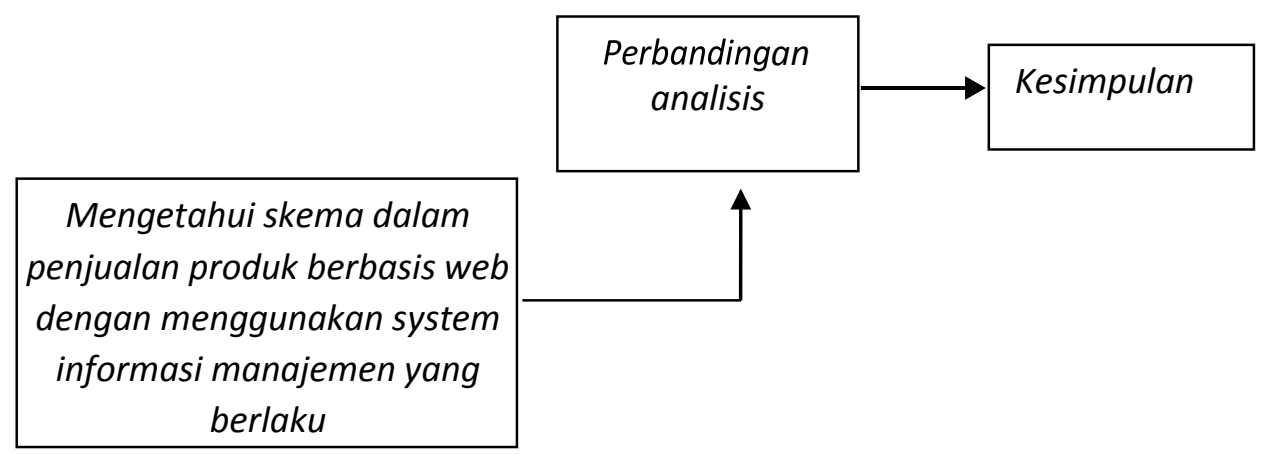

\section{Keterangan :}

Pada penelitian ini, peneliti melakukan penjelaskan mengenai system informasi manajemen penjualan thrift toko Yegumi berbasis web yang diterapkan di dalam toko tersebut yang dikaitkan dengan kajian teoritis yang terdapat pada kajian-kajian sebelumnya. Selain itu, penelitian ini juga menjelaskan mengenai skema-skema penjualan dengan menerapkan sistem informasi manajemen yang sudah berlaku . Studi perbandingan yang dimaksud adalah dalam bentuk analisis kuantitatif deskriptif. 
Jenis Penelitian :

Dalam penelitian ini penulis menggunakan metode deskriptif kualitatif. Data kualitatif merupakan informasi dalam bentuk kalimat bukan berupa angka maupun symbol. Dengan menggunakan penelitian kualitatif, peneliti dapat mengetahui subyek dan mengetahui keadaan yang dialami mereka dalam kehidupan sehari-hari.Penelitian kualitatif juga menghasilakn data deskriptif. Data deskriptif merupakan data yang rinci, menjelaskan suatu masalah dengan jelas sampai ke akarnya, dan menjelaskan suatu fenomena secara detail. Metode ini bertujuan untuk mengetahui gambaran jelas menganai masalah dengan utuh dan sesuai fakta sesuai gambaran manusia yang melakukan penelitian.

\section{Subjek Penelitian}

Subyek penelitian ini adalah toko Yegumi thrift di Tulungagung Jawa Timur. Obyek pada penelitian ini yaitu data mengenai penjualan baju dengan berbasis web dengan mengunakan sistem informasi manajemen yang berlaku

\section{Teknik Pengumpulan Data}

a. Mengumpulkan data

Pada kegiatan ini, penulis melakukan pengumpulan data guna untuk menunjang pembangunan sistem. Pengumpulan data dilakukan dengan cara wawancara yaitu melakukan tanya jawab pada perusahaan yang menjadi tempat penulis untuk melakukan pembangunan sistem ini. Selain itu penulis juga mengumpulkan data dengan cara studi literatur yang bertujuan sebagai panduan untuk melakukan pembangunan sistem dan sebagai panduan untuk pembuatan laporan mini riset ini.

b. Menentukan ruang lingkup

Pada kegiatan ini, penulis menentukan ruang lingkup dalam pembuatan smini riset ini Menentukan ruang lingkup tersebut dilakukan penulis ini memiliki batasan - batasan mengenai apa yang akan dibuat dan dikerjakan .

c. Dentifikasi permasalah

Pada kegiatan ini, penulis melakukan identifikasi permasalahan yang ada pada bagian By Product. Kemudian permasalahan - permasalahan yang teridentifikasi tersebut penulis tuangkan pada mini riset ini dan mencari pemecahan masalahnya. 


\section{Teknik Analisa Data}

1. Reduksi Data;

Reduksi data merupakan pemsuatan perhatian, proses pemilihan pada pengabstrakan, penyederhanaan dan transformasi data yang kasar yang muncul daricatatan dilapangan

2. Penyajian Data;

Penyajian data ini tersusun berbagai informasi yang bisa terjadi pengambilankeputusan dan penarikan kesimpulan. Setelah itu penyajian data digunakan agar dapat memahami masalah yang diteliti serta dianalisis sesuai dengan tujuan yang diinginkan.

3. Menarik Kesimpulan;

Menarik kesimpulan dengan cara pengembangkan sebuah paragraf lalu menarik sebuah gagasan utama dan simpulan umum berdasarkan kerjadian yang ada. Selain itu penarikan kesimpulan dapat dilakukan dengan cara pengembangan sebuah paragraf menggunkan sebab akibat. kesimpulan hanyalah sebuah sebagian dari pembahasan yang ada. Kesimpulan dibuat agar pembeca bisa memahami secara singkat dari pembahasan sebelumnya. Saat penelitian berlangsung kesimpulan juga diverifikasi terlebih dahulu.

Dalam Artikel ini menggunakan metode analisis data kualitatif. Metode analisis data kualitatif adalah pendekatan pengolahan secara mendalam data hasil pengamatan, wawancara, dan dari data angket yang telah kami buat. Sistematika atau urutan yang ada dalam penelitian memberikan pola berfikir secara sistematis, komplek dan mampu mengungkan gejala yang ada dimsyarakat secara sistematis. Penelitian kualitatif tidak dapat ditolak kebenarannya oleh masyarakat, karena penelitian ini dibuat sesuai keadaan nyata dilapangan.

\section{Instrumen Penelitian}

1. Studi kepustakaan

Studi kepustakaan ini dilakukan dengan cara membaca literatur-literatur yang berhubungan dengan permasalahan yang sedang diteliti dan dapat dijadikan sebagailandasan teoritis bagi pembahasan masalah.

2. Metode interview (wawancara)

Metode wawancara dilakukan dengan cara wawancara dengan pihak-pihak yang terkait dengan penelitiaan 


\section{PEMBAHASAN}

\section{Prosedur Sistem yang Berjalan dalam Penjualan Thrift Toko Yegumi}

Setiap toko pasti memiliki metode dalam berjualan. Ada yang menggunakan metode online dengan menggunakan web ada juga yang berjualan dengan cara bertransaksi langsung dengan pembeli. Semua metode itu memiliki dampak positif dan negative masing-masing. Contoh saja dalam toko Yegumi ini menjual baju Thirft. Untuk memasarkan produknya mereka menggunakan media sosial. Hal itu dikarenakan, produk mereka yaitu Thirft atau baju bekas masih belum terlalu dikenal banyak konsumen. Maka dari itu mereka menggunakan media sosial agar mudah dikenal atau dilihat banyak orang. Memang benar, sebaiknya kita harus mengikuti perkembangan zaman agar bias bersanding dengan toko-toko yang lain. Dizaman yang canggih atau modern ini mengharuskan kita untuk menggunakan barang elektronik untuk mendukung segala aktivitas. Kita mengirim video atau foto produk sekali saja sudah bisa tersebar atau dikenali oleh berbagai orang dari plosok negeri pun juga akan mengetahui.

Toko yegumi juga memperhatikan sasaran pasarnya, karena toko yegumi menjual baju dengan model korean style yang cocok untuk kalangan remaja dan dewasa. Dari hal itu Menurut mbak Yeye sebagai Owner dari toko Yegumi menjelaskan bahwa tokonya mulai menggunkan motede online store atau membuka toko agar konsumennya juga bias melihat langsung produk yang mereka jual. Hal tersebut memang sangat memudahkan bagi konsumen yang MELEK teknologi. Mereka dapat berbelanja dengan mudah juga, tanpa harus order via online. Selain itu, ada kelemahan dari metode tunai yaitu Proses pencatatan dan perhitungan transaksi pelanggan yang dilakukan secara manual, sehingga waktu untuk melakukan tersebut menjadi lama. Pencatatan transaksi ditulis pada media kertas, sehingga membutuhkan banyak kertas untuk setiap hari transksinya. Jadi biaya untuk melakukan pencatatan transaksi menjadi lebih besar. Kurang lengkapnya dokumen dan catatan akuntansi maupun sistem otorisasi menyebabkan ketidak sesuaian informasi penjualan yang dihasilkan pada system yang berjalan saat ini. 
Berikut ini skema penjualan dari Toko Yegumi baik menggunakan system penjualan menggunakan web maupun bertransaksi langsung:

\section{a. Sistem Penjualan Berbasis Web}

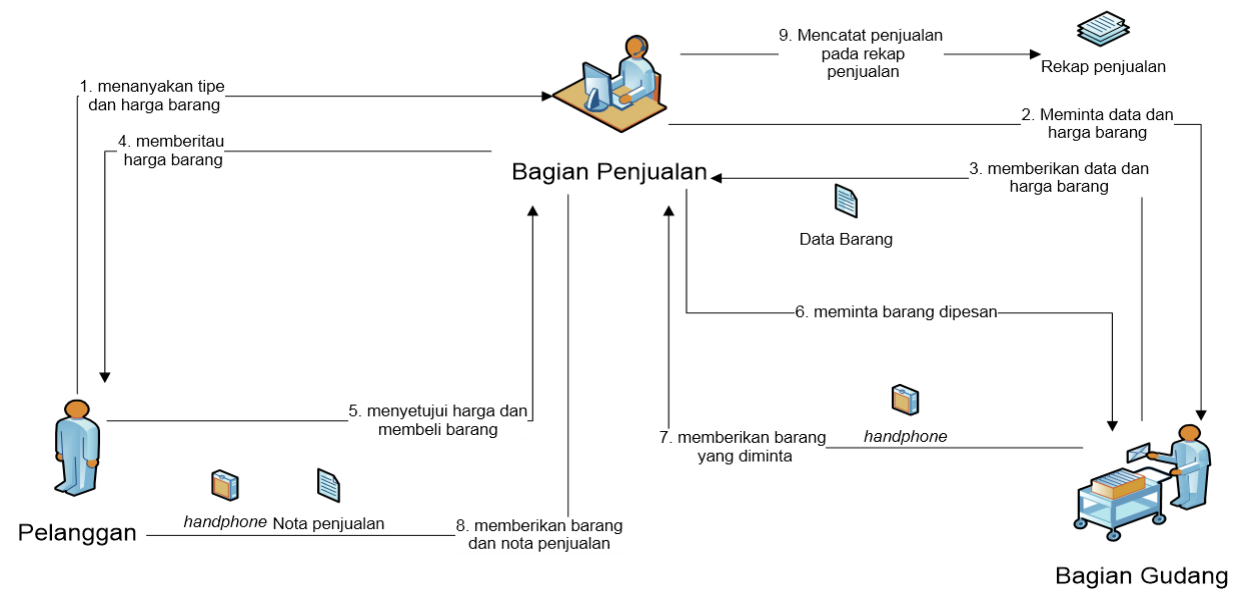

Dalam proses penjualan, pelanggan telah melihat catalog baju dalam web toko Yegumi. Selanjutnya, pelanggan akan memesan produk yang diinginkan melalui website toko atau $e$ commerce. Atau bisa juga melakukan pemesanan melalui chat admin menggunakan aplikasi whatsapp. Setelah pelanggan memesan barang yang diinginkan, barang akan diproses dan dilayani oleh bagian penjualan. Selain itu, pelanggan juga bisa menggunakan e-commerce seperti shopee agar mendapatkan biaya ongkos kirim yang lebih murah. Pelanggan dapat menanyakan harga dan model baju yang ingin dibeli kepada bagian penjualan. Umumnya pelanggan yang membeli baju Thirft Toko Yegumi adalah para sesama penjual baju thrift untuk dijual kembali, tetapi toko juga melayani pelanggan umum yang membeli satuan namun dengan harga yang berbeda. Pelanggan yang ingin membeli dapat langsung menanyakan jenis baju yang akan dibeli kepada bagian penjualan, kemudian bagian penjualan akan bertanya kepada bagian gudang apakah baju yang diinginkan pelanggan ada. Jika barang ada, bagian gudang akan memberi tahu kepada bagian penjualan apabila produk tersebut stock nya masih ada. Setelah bagian penjualan konfirmasi ketersediaan barang kepada pelanggan, palanggan dapat melakukan format order dengan mengirimkan informasi terkait barang yang dibeli seperti nama produk / kode produk, nama pembeli, nomor hp pembeli serta alamat dimana barang akan dikirim. Apabila sudah melakukan format order, bagian penjualan akan membuatkan nota total produk pembelian serta biaya ongkos kirim apabila pembeli berada di luar kota. Untuk metode pembayaran secara online dapat dilakukan dengan cara transfer antar Bank atau melakukan pembayaran non-tunai melalui minimarkert. Pelanggan tetap diberikan batas waktu 2 hari untuk pembayaran atau bisa menggunakan motede $C O D$ (Bayar ditempat) untuk $e$ - 
commerce seperti shopee. Setelah pembayaran selesai, maka, penjualan akan menyerahkan barang tersebut kepada kurir agar barang segera dikirim. Estimasi pengiriman sesuai dengan jarak yang akan ditempuh.

\section{b. Sistem Penjualan Berbasis Tunai (Transaksi langsung antara penjual dan pembeli)}

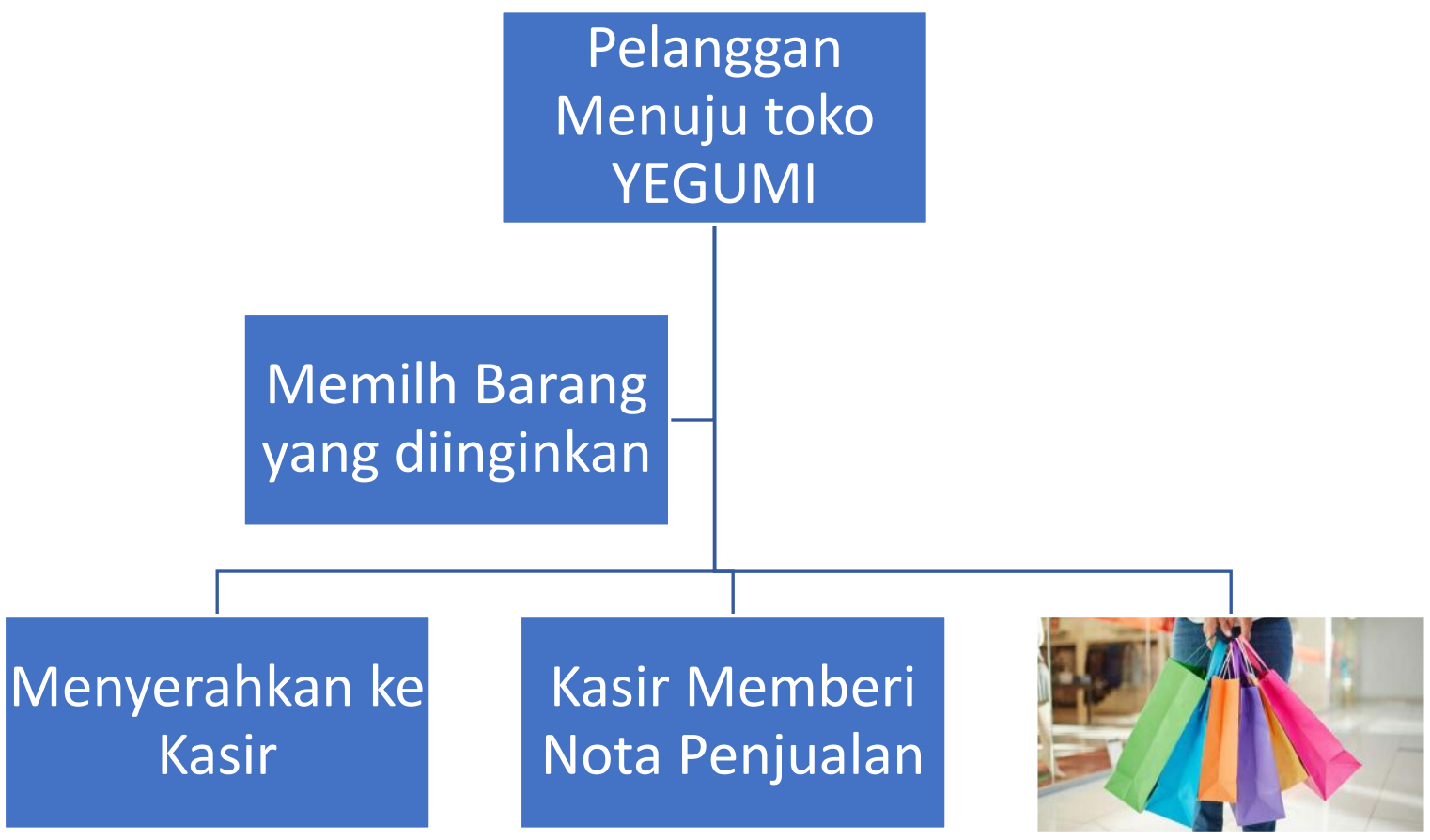

Dalam metode ini, memang cukup mudah digunakan. Yang terpenting kita harus mengetahui lokasi dari toko tersebut. Menurut mbak Yeye sebagai owner dari toko Yegumi menjelaskan bahwa masih banyak orang yang lebih suka belanja dengan datang ke toko langsung. Untuk yang pertama, pelanggan datang ke toko terebut. Setalah itu, pelanggan bebas memilih baju yang mereka inginkan, untuk kelebihan datang ke toko yaitu kita bias mengetahui langsung mengenai detail bahan, model dan bisa mencooba lansung baju tersebut. Setelah pelanggan mendapatkan produk, pelanggan akan mengetahui informasi harga produk tersebut ke pegawai toko dan jika barang tang dipilih pelanggan merupakan barang lama maka ada kemungkinan akan mendapatkan diskon. Pelanggan yang sudah memantapkan pilihan produknya untuk dibeli selanjutnya menyerahkan barang ke kasir untuk melakukan pembayaran dan diberikan nota pembelian serta pembungkusan produk yang telah dibeli. 
Setelah itu, baju sudah bias kita bawa pulang. Jadi sebenarnya semua dua metode tersebut memiliki kemudahan dan kekurangan. Maka dari itu, kita bisa menyesuaikan kebutuhan saja.

\section{Cara Menganalisis Kendala pada System Penjualan Thirft Sebelum Berbasis Web.}

Pada analisis kendala atau permasalahan yang terjadi, penelitian mini riset ini menggunakan metode permasalahan dengan kerangka PIECES [5] yaitu :

1. Performance (Kinerja)

- Lambatnya proses pembuatan laporan-laporan yang diperlukan oleh owner.

- Adanya pemborosan waktu untuk mengetahui ketersediaan stok thrift yang membuat kinerja toko kurang efektif dan efisien.

2. Information (Informasi)

- Kurangnya jangkauan informasi mengenai thrift kepada masyarakat.

- Informasi penjualan dan persediaan barang tidak dapat diberikan secara realtime kepada owner.

3. Economics (Ekonomi)

- Owner mengalami kesulitan untuk mencari tahu pelanggan yang paling banyak melakukan transaksi pembelian dalam periode tertentu.

- Owner mengalami kesulitan untuk mencari tahu produk mana yang paling laris dan yang tidak laris ketika dipasarkan.

4. Control (Kontrol)

Informasi data penjualan, pembelian, dan stok barang dapat diakses oleh orang yang tidak berhak.

5. Efficiency (Efisien Waktu)

Sering kali terjadinya keterlambatan dalam mengetahui persediaan barang yang diinginkan pelanggan.

6. Service (Layanan)

- Proses transaksi yang dilakukan terhadap pelanggan mengakibatkan sering kali tidak puasnya pelanggan terhadap kinerja karyawan.

- Belum adanya laporan berbentuk grafik ataupun tools lainnya sehingga Owner tidak dapat menganalisis data transaksi secara detail tentang perkembangan Toko.

Dalam suatu peradaban yang semakin hari semakin maju dibutuhkan evaluasi guna untuk mengetahui system yang terbaik untuk menghasilkan kinerja yang optimal. Banyaknya 
kendala yang terjadi pada penjualan thrift Toko Yegumi membuat owner mulai bergerak untuk menganalisis dan mencari solusi akan masalah yang terkait. Dengan mengetahui cara untuk menganalisis kendala yang terjadi akan semakin tepat juga cara untuk memperbaiki system yang digunakan pada penjualan thrift Toko Yegumi. Sistem Informasi Manajemen yang tepat Memudahkan pihak manajemen untuk melakukan perencanaan, pengawasan, pengarahan dan pendelegasian kerja kepada semua departemen yang memiliki hubungan atau koordinasi dan juga meningkatkan produktivitas dan penghematan biaya.

\section{Output Sistem Informasi Manajemen Pada Penjualan Thrift Toko Yegumi}

Setiap adanya pemasukan dan pengeluaran tentunya dilakukan pencatatan guna untuk mengetahui berapa banyak pengeluaran setiap bulannya dan juga untuk mengetahui seberapa banyak laba yang diperoleh dari penjualan thrift Toko Yegumi. Sistem laporan keuangan pada Toko Yegumi menggunakan 2 cara yaitu dilakukan secara manual (pencatatan buku) dan secara digital (sistem komputer). Untuk laporannya sendiri akan dikirimkan oleh admin penjualan pada periode akhir bulan atau bulanan. Rincian untuk laporan keuangan yaitu terkait kualitas barang (barang terjual dan barang belum terjual), harga pembelian, total pendapatam (keuntungan) dan metode pembayaran (tunai atau non-tunai). Sistem laporan keuangan toko Yegumi database menggunakan Ms. Excel untuk memantau pendataan, penjualan dan laporan keuangan.

Toko Yegumi pun melakukan evaluasi seperti evaluasi produk. Untuk evaluasi produknya sendiri akan dilihat dari produk yang kurang, untuk produk yang kurang diminati selanjutnya akan di sale dengan harga diskon atau untuk bonus pembelian apabila melakukan pembelian dengan minimal pembelian nominal yang ditentukan. Target penjualan toko Yegumi ini menargetkan pendapatannya mencapai Rp. 700.000 - Rp. 1.000.000/ harinya dengan target keuntungan per produknya terjual $10-30 \%$. 


\section{PENUTUP}

\section{KESIMPULAN}

Sistem Informasi Manajemen berbasis web yang digunakan pada penjualan thrift Toko Yegumi. Toko ini memiliki metode dalam berjualan yaitu dengan menggunakan metode online dengan menggunakan web ada juga yang berjualan dengan cara bertransaksi langsung dengan pembeli. Semua metode itu memiliki dampak positif dan negative masingmasing. Dalam suatu peradaban yang semakin hari semakin maju dibutuhkan evaluasi guna untuk mengetahui system yang terbaik untuk menghasilkan kinerja yang optimal. Banyaknya kendala yang terjadi pada penjualan thrift Toko Yegumi membuat owner mulai bergerak untuk menganalisis dan mencari solusi akan masalah yang terkait. Dengan mengetahui cara untuk menganalisis kendala yang terjadi akan semakin tepat juga cara untuk memperbaiki system yang digunakan pada penjualan thrift Toko Yegumi. Sistem Informasi Manajemen yang tepat Memudahkan pihak manajemen untuk melakukan perencanaan, pengawasan, pengarahan dan pendelegasian kerja kepada semua departemen yang memiliki hubungan atau koordinasi dan juga meningkatkan produktivitas dan penghematan biaya .

\section{SARAN}

Berdasarkan hasil analisis dan pembahasan yang telah dilakukan, ada beberapa saran yang dapat dijadikan acuan positif dan pengembangan sistem informasi manajemn yang telah dibuat guna memberikan hasil yang baik dan dapat bermanfaat bagi perusahaan, antara lain :

1. Sistem yang ada ini masih mengalami kelemahan diantaranya masih bisa terjadi kerusakan system sehingga data yang ada harus di back up sehingga data yang ada tetap aman.

2. Dilakukan pengembangan sistem, karena sistem yang ada sekarang berbasis web maka toko dapat mengembangkan sistem dengan berbasis mobile agar pemiliki toko lebih mudah mengakses informasi transaksi perusahaan.

3. Perlu dilakukan peningkatan mengenai penjualan agar bias bersaing dengan pihak lain dengan mengikuti trend saat ini

4. Untuk peneliti selanjutnya, hasil penelitian ini bias digunakan sebagai bahan perbandingan dan referensi untuk penelitian, dan sebagai bahan untuk pertimbangan untuk lebih memperdalam penelitian selanjutnya dengan menggunakan system informasi manajemen pada penjualan toko maupun perusahaan. 


\section{DAFTAR PUSTAKA}

Heryana, A., \& Unggul, U. E. (2018). SISTEM : Teori, Pengertian dan Berfikir Sistem Aplikasi dalam Bidang Kesehatan. November 2017, 1-36.

Laudon. (2010). Pengertian Sistem Informasi.

Murdick dan Ross. (2005). Chemical Information and Modeling. Journal of Chemical Information and Modeling, 53(9), 11.

Prabowo, R. G. M. (2015). PENGEMBANGAN SISTEM. Pengembangan Sistem Informasi.

Purnama, C. (2016). Sistem Imformasi Manajemen. 2(1), 159-168.

Rahmat, H. (2010). Pemrograman web. Pemrograman Web Dengan Html, 6-20. 